\title{
Justice and unconditional valuing in Nietzsche's Genealogy
}

\author{
Christopher D. Cordner
}

Towards the middle of the middle essay of Nietzsche's Genealogy of Morals we find this remarkable passage:

If it really happens that the just man remains just even toward those who injure him (and not merely cold, moderate, distant, indifferent: being just is always a positive way of behaving), if the high, clear objectivity - that sees as deeply as it sees generously - of the just eye, the judging eye, does not cloud even under the assault of personal injury, derision, accusation, well, then that is a piece of perfection and highest mastery on earth - what is more, something one would not be prudent to expect here, in which one in any case would $(0)$ not all too easily believe. ${ }^{1}$

This passage expresses, I think, profound admiration for the just person in whom 'the just eye' remains unclouded even under the greatest personal assault. More specifically, it is this person's orientation to justice for which Nietzsche has such profound regard. Broadening my reflections both to the surrounding context of the passage and to still wider considerations about Nietzschean genealogy will first help to clarify why I think Nietzsche's profound regard for 'the just man' is regard for an unconditionally just orientation. It will also help us see how reading him this way is not only compatible with, but in fact supports and is supported by, various specific themes of the Genealogy that at first glance may appear directly opposed to my reading. A reading of this passage thereby takes its place in a wider recasting of aspects of Nietzsche's maturest thinking about value.

What might warrant regarding someone's orientation to justice as unconditional? One obvious consideration is that there be no conditions on that person's refusal to do what is unjust. He will refuse to do what is unjust, come what may. More positively, he will remain just, come what may

This is the author manuscript accepted for publication and has undergone full peer review but has not been through the copyediting, typesetting, pagination and proofreading process, which may lead to differences between this version and the Version record. Please cite this article as doi:10.1111/ phil.12145. 
- that is, unconditionally. (Later, we will see reason to be more precise about what his 'remaining just' involves.) My initial suggestion is that Nietzsche's words in the passage we began with express his own unqualified admiration for the one who manifests such an orientation - the one in whom the just eye, the judging eye, [will] not cloud even under the assault of personal injury, derision, accusation'. (While Nietzsche speaks of 'the just eye' - just seeing or judging - he also speaks of 'remaining just' and says that being just is a 'way of behaving'; so he is evidently not concerned with 'the just eye' rather than with just response, but with both.)

The adherence to justice Nietzsche here envisages, then, seems to be one on which there are no 'conditions': this person described by Nietzsche will retain 'the just eye' under even the most extreme assault of 'injury, derision, accusation'. Of course, one might reckon that any such orientation must either be insincere, or if sincere then at least unlivable by the one making it. That response would manifest the conviction that whatever anyone says and however she says it, there can be no unconditional valuing of justice. But this is not the light in which Nietzsche casts the outlook he presents. Nietzsche presents his 'piece of perfection' both as a real human possibility and also as one eliciting his own deepest admiration. Of course he does enjoin caution: he says that the 'piece of perfection' he envisages is '...something one would not be prudent to expect here, in which one in any case would not all too easily believe'. But we should not misread that sober acknowledgment as qualifying his admiration for such an orientation. He is simply reminding us here how rare this piece of perfection will be.

In speaking of a simple, even naïve, reading of the Nietzsche passage I have so far confined attention to just these words of Nietzsche's text. But we are so ready to read Nietzsche in a certain way that it is hard to avoid thinking this naïve reading must be mistaken, and that this will become clear as soon as we consider those words in the wider context of Nietzsche's text. That is exactly what I shall call into question. Wider attention to Nietzsche's text will in fact bring out the real substance and weight of this initial reading, showing how it is both held in place by, and also illuminates, important aspects of the broader text. I begin, though, by considering one way in 
which my initial naïve reading might be thought undermined even by a clause in the passage already quoted.

Nietzsche says that if someone really does remain just even in those extreme circumstances, then 'that is a piece of perfection and highest mastery ['und höchster Meisterschaft'] on earth' [my italics]. What these words make clear, it may be said, is that Nietzsche's praise is not for the justice of the just man's orientation, but instead solely for the mastery exemplified by his remaining just in the circumstances envisaged. Reading the passage this way then plausibly sees it as reiterating a valuing of the master-type that is not only recurrent in the Genealogy, but also runs through Nietzsche's mature thinking. If there is something whole-heartedly affirmed here, ${ }^{2}$ then, it is not 'the just man' as just, but rather the mastery exemplified in the noble type.

That reading of the passage is surely further confirmed, it may be said, by another aspect of the passage's immediate context. The passage is part of Nietzsche's response to Dühring's insistence that 'the homeland of justice is to be sought on the ground of reactive feeling' [my italics]. 'Absolutely not', Nietzsche says. On the contrary:

the entire administration of justice, also the true need for justice, [has] thus far been at home on earth...in the sphere of... the active, strong, spontaneous, aggressive [men]... [J]ustice on earth represents... precisely the battle against reactive feelings, the war against them on the part of the active and aggressive powers that have used their strength in part to call a halt to and impose measures on the excess of reactive pathos and to force a settlement. ${ }^{3}$

Is it not clear, then, that the real object of praise in the passage we began with is simply meisterschaft - the mastery which, given it involves freedom from reactive and therefore slavish responses, is crucially the self-mastery, of Nietzsche's master-type?

My answer is: no, that is very far from clear. Indeed I think it is simply not so. Let it be granted that Nietzsche is praising the self-mastery of the just person he describes. That doesn't mean that he is not - not really - here affirming the just man's orientation to justice. Even if the 
link with mastery in the immediate and also the broader context of our passage is strong, still, in the quoted passage itself Nietzsche neither says nor implies that the real ground of this 'piece of perfection' is the mastery she displays. The German is: 'so ist das ein Stück Vollendung und höchster Meisterschaft auf Erden'. The Clark and Swensen translation - 'then that is a piece of perfection and highest mastery on earth' - sticks very close to the original. Neither the German nor the translation says, or obviously suggests, that the orientation described is a piece of perfection only because it exemplifies the highest mastery. Were that Nietzsche's thought, it certainly could have been much less obscurely expressed, for example by reordering the words and clarifying the link between the key phrases like this: 'then that is the highest mastery and so a piece of perfection on earth.' Nietzsche's actual words are most naturally read as saying that the fidelity to remaining just that he has described is a piece of perfection - of a kind that, yes, we can then also recognize as an expression of mastery.

But this is not just a fine point about Nietzsche's actual words in a single clause. There is simply no independent reason to think greater self-mastery is displayed by responding as Nietzsche' s exemplar does rather than by (say) simply dealing aggressively with the person who visits such personal injury and derision upon one. Let me be clearer about what I mean by that. One will see Nietzsche's exemplar as masterful only so far as one finds his just orientation to be imaginatively, humanly, morally compelling. For what is there 'masterful' simply in someone failing to take steps necessary to protect himself from another person assaulting, injuring and perhaps destroying him? That surely will look like nothing more than a piece of stupid or weak self-abandonment, even self-cancelling, unless one sees the man's refusal to protect himself that way as here expressive of an orientation to justice that one finds compellingly admirable. Then one can recognize his orientation as manifesting meisterschaft: 'how wonderfully masterful that someone could 'remain just' even under that kind of assault!' But Nietzsche's praise for meisterschaft in the passage then in no way undermines reading him as affirming unwavering 
fidelity to justice as itself a piece of perfection. On the contrary, the praise makes sense only against the background of such an affirmation.

The relation here implied between meisterschaft and this just orientation points to the very idea of meisterschaft having undergone a subtle transformation: its highest form in this 'piece of perfection' has come apart from 'aggressiveness' and the disposition to 'attack' and 'encroach'. In specifying how Nietzsche registers this subtle transformation we begin to move out from the passage in question to its place in the wider text:

Even with the most righteous persons it is certain that a small dose of attack, malice, insinuation is, on the average, already enough to chase the blood into their eyes and the fairness out. The active, the attacking, encroaching human being is still located a hundred paces nearer to justice than the reactive one; he simply has no need to appraise the object $r(\cos$ falsely and with prejudice as the reactive human does, must do. Therefore in all ages the aggressive human, as the stronger, more courageous, more noble one, has in fact also had the freer eye, the better conscience on his side... ${ }^{4}$

This 'active, aggressive, stronger, more courageous, more noble' character is contrasted with 'the reactive one'. But even though he is 'a hundred paces nearer to justice' than the reactive person, he (the active, aggressive character) is not ipso facto the 'piece of perfection' that is Nietzsche's truly just person. And if we ask 'why not, what is he lacking?', the only fully adequate answer to that question is, precisely: justice, spelt out as 'the high, clear objectivity - that sees as deeply as it sees generously - of the just eye, the judging eye, [that] does not cloud even under the assault of personal injury, derision, accusation.'

If we keep our eye clearly on this point, we can also avoid misreading some sentences I quoted earlier, about 'the entire administration of justice' being at home in the sphere of the active, strong, spontaneous, aggressive character. They do not support the view that Nietzsche's praise in the passage we began with is for mastery rather than for justice. They are expressly about the administration of justice - the practice of justice in bringing about and maintaining a 
certain sort of public, social world. That practice undoubtedly calls for 'active and aggressive powers that have used their strength in part to call a halt to and impose measures on the excess of reactive pathos and to force a settlement'. But someone could be a most effective such administrator of justice, without at all being the 'piece of perfection' Nietzsche speaks about in the earlier passage. Justice in that admired exemplar is not the practice of such administration; it is manifest in something different and distinctively marvelous. The aggressiveness needed for subduing unruly others abruptly and often forcefully when administering justice is simply not engaged in one remaining just in the circumstances Nietzsche describes - under the assault of personal injury, derision and accusation. There, such aggressiveness may even be a real hindrance: Nietzsche actually says that it is what leads 'even the most righteous persons' not to be able to respond in the way of Nietzsche's 'piece of perfection' - to respond instead with 'blood' rather than 'fairness' in their eyes. In one who retains the just eye under extreme personal assault something very different indeed from aggressive powers finds expression.

Admittedly, in the passage in question Nietzsche says 'the entire administration of justice, also the true need for justice [my italics] (has) thus far been at home...in the sphere of the... aggressive (human)'. That might sound as if Nietzsche thinks all justice is and must be 'at home' in that sphere. But Nietzsche is here 'look(ing) around in history', at where justice has thus far been at home. This is justice 'considered historically'. ${ }^{5}$ While it is very important to remember this history, it is equally important not to see Nietzsche as equating what justice is or can be with its history. And in the passage we began with, Nietzsche is (I am suggesting) envisaging an orientation to justice that exceeds, by creatively transforming, its history. Below I clarify how Nietzsche's own account of genealogy explicitly orients us to the possibility of such creative transformation.

It would be simply question-begging to argue that because Nietzsche links the administration of justice with aggressiveness, he cannot make sense of, let alone admire, an expression of justice not dependent on aggressiveness and arguably at odds with it. Like other values, justice can, on 
Nietzsche's picture, be realized in different ways, which can be more or less moving, impressive, and imaginatively compelling. (I pick this point up again below.) As an exemplar of justice with its own distinctively marvelous attraction, the 'piece of perfection' Nietzsche holds before us is certainly a startling moment in his text. But it is important to appreciate that Nietzsche's whole framing of genealogy, as well as his account in the Genealogy of the genealogy of justice in particular, opens up the space of possibility for such a moment.

To bring out how it does so, it will help to have the main lines of that specific genealogy before us. These are set out both before and after the passages in the Genealogy that we have so far been looking at:

...the oldest and most naive moral canon of justice ...is the good will among parties of approximately equal power, their readiness to come to terms with one another, to reach an "understanding" again by means of a settlement - and in regard to less powerful parties, to force them to a settlement among themselves. ${ }^{6}$

There are two ideas here: one is about the origins of justice lying in aristocrats 'of approximately equal power' being ready to 'come to terms with one another'; and the second is about the extension of such coming to terms, by force, over 'less powerful parties'. Nietzsche then spells out this process of extension. The context for this discussion is his vehement rejection, already touched on, of 'Dühring's ... proposition that the homeland of justice is to be sought on the ground of reactive feeling' - 'hate, envy, ill will, suspicion, rancor, revenge'. On the contrary, says Nietzsche:

Everywhere justice is practiced and upheld one sees a stronger power seeking means to put an end to the senseless raging of ressentiment among weaker parties subordinated to it...in part by... raising certain equivalents for injuries to the status of a norm to which ressentiment is henceforth...restricted. But the most decisive thing the highest power does is... the establishment of the law, an imperative declaration of what is to count in its eyes as permitted, as just, what is forbidden, as unjust: after it has established the law, it treats 
infringements and arbitrary actions of individuals or entire groups as wanton acts against the law, as rebellion against the higher power itself, thereby diverting the feeling of its subjects away from the most immediate injury caused by such wanton acts and thus achieving in the long run the opposite of what all revenge wants, which sees only the viewpoint of the injured one, allows it only to count - from now on the eye is trained for an ever more impersonal appraisal of deeds, even the eye of the injured one himself (although this last of all, as was mentioned at the start). ${ }^{7}$

And this passage adds a further theme: the progressive inculcation in human beings of a selfunderstanding that incorporates the impersonal perspective of justice. Our 'training' under 'the law' originally imposed by that 'higher power' develops in us the ever more impersonal 'eye' of justice. Eventually it becomes possible for even the one offended against to see with that eye. With some exceptions, each person thus becomes someone whose sense of himself - to put the point in terms Nietzsche admittedly does not explicitly use - is constituted under the aegis of his seeing things 'ever more impersonally'. (Nietzsche is careful here. He speaks of 'an ever more impersonal' appraisal not a 'wholly impersonal' one, implying that even in those - most of us in whom the training has taken effect, other perspectives, for instance one of vengeance or one of self-protection, will likely still find purchase.) The perspective of justice in this way becomes partly constitutive of who we are. Nietzsche is not committed, though, to thinking that this training is effective in everyone - hence the exceptions. A very few people remain - as Aristotle might put it - 'brutishly' almost completely unaffected by this 'training', while others do not get beyond being merely 'extrinsically' motivated to justice. (I clarify 'extrinsically' below.)

This genealogical story opens up a space within which Nietzsche's 'piece of perfection' just might come to pass. It remains important that there are no necessities here. 'Even... the most righteous persons' commonly fall short of such 'perfection' of justice: their adherence to the impersonal perspective gives out well short of the circumstances of extreme personal injury and derision that Nietzsche describes. But with the possibility of even the offended person coming to 
see with that eye of justice, there is the further possibility, however remote and unlikely, of that 'piece of perfection' Nietzsche envisages. The realizing of that possibility has been prepared for, as it were, along the historical path Nietzsche traces, but it will be in fact realized only in the rare circumstance when some particular, unusual human being specifically comes to embody it.

One thing I am pointing to here is the anti-reductive character of Nietzschean genealogy. Nietzsche has sketched (what he claims to be) the historical conditions of justice's emergence, including the conditions of its cultural entrenchment as an idea seminal in structuring the modern world. ${ }^{8}$ But it is a very clear theme of genealogy as Nietzsche understands it, to allow for the possibility of unforeseeable transformations of what has developed contingently in the way our ideas and practices of justice have done: ${ }^{9}$

...for history of every kind there is no more important proposition than [this]... that the cause of the genesis of a thing and its final usefulness, its actual employment and integration into a system of purposes, lie toto caelo apart; that something extant, something that has somehow or other come into being is again and again interpreted according to new views, monopolized in a new way, transformed and rearranged for a new use by a power superior to it; that all happening in the organic world is an overpowering, a becoming-lordover, and that, in turn, all overpowering and becoming-lord-over is a new interpreting, an arranging by means of which the previous "meaning" and "purpose" must of necessity be obscured or entirely extinguished. ${ }^{10}$

Nietzschean genealogy does not identify origins and then say that everything that grows from those origins can be understood solely in the terms needed to describe the origins. On the contrary, genealogy allows for the coming into the human world of all manner of things that exceed their origins and are in this way new. ${ }^{11}$ This is already evident in the literal idea of genealogy that Nietzsche metaphorizes: my genealogy sets out my ancestry, where (or who) I came from. In doing this it can help explain me - 'from this one he gets his nose, and from that one his hot temper'. But reference to my ancestors will not afford all the terms needed for 
understanding me. Other terms will also be needed for understanding this new being that emerged from those parents and grandparents. There is a genealogy for every child; and every child is also a new being, needing to be understood in a way that is receptive to whatever novelty she manifests. It is this way, too, for the new 'uses' of the thing whose genealogy is traced by Nietzsche - justice and guilt in the Genealogy, for example. The genealogical method of Nietzsche's historical philosophy is thus explicitly anti-reductive, allowing for the new - that is, the not-wholly-determined-by-the-past-out-of-which-it-emerges - to appear. That is the Nietzschean philosophical context for the remarkable phenomenon of that 'piece of perfection' Nietzsche describes and affirms. In affirming it, Nietzsche himself expresses profound regard for an orientation of justice exceeding anything needed for the social and cultural work done by the administration of justice whose origin and development he has sketched. The fact that the orientation of his 'piece of perfection' is not explicable in terms of its contribution to maximizing the cultural 'conditions of justice' is no reason, in Nietzsche's genealogical outlook, for dismissing it. $^{12}$

Let me take stock. Here are four things (among others) that I have argued. One is that attention to Nietzsche's actual words makes it implausible to read the passage we began with as affirming only the value of meisterschaft. The second point is that there is anyway a real difficulty in seeing how it could be affirming the value of meisterschaft unless the orientation of justice there expressed was already itself valued. Thirdly, that aggressive powers may be required in those undertaking the administration of justice says little or nothing about what is needed for the just orientation of Nietzsche's 'piece of perfection'. And the fourth thing I have argued is that the thrust of Nietzschean genealogy actually opens up a space for the reading of Nietzsche I am undertaking to defend.

By drawing on these themes I hope to have undermined some reasons for resisting a reading of Nietzsche as profoundly affirming an unconditional orientation to justice. But even if I have done that, still I am well short of having made the reading compelling. And there are other 
elements of Nietzsche's text that seem to warrant strong resistance to any such reading. Here is a key passage, in the same section of the middle essay as the passage we began with:

Accordingly, only once the law has been established do 'justice' and 'injustice' exist...To talk of justice and injustice in themselves is devoid of all sense; in itself injuring, doing violence, pillaging, destroying naturally cannot be 'unjust', insofar as life acts essentially that is, in its basic functions - in an injuring, violating, pillaging, destroying manner and cannot be thought at all without this character. One must even admit to oneself something still more problematic: that is, from the highest biological standpoint, conditions of justice can never be anything but exceptional conditions, as partial restrictions of the true will of life - which is out after power - and subordinating themselves as individual units to its overall end: that is, as means for creating greater units of power. A legal system conceived of as sovereign and universal, not as a mean in the battle of power complexes, but rather as a means against all battle generally, say in accordance with Dühring's communist cliché that every will must accept every other will as equal, would be a principle hostile to life, a destroyer and dissolver of man, an attempt to kill the future of man, a sign of weariness, a secret pathway to nothingness. ${ }^{13}$

At least two themes here might seem to put paid to my reading. First, if talk of justice 'in itself' ['an sich'] is 'devoid of all sense', justice then cannot coherently have any value in itself, let alone unconditional value. And in that case, profound regard for an unconditionally just orientation is surely also incoherent. Secondly, the long last sentence of the passage makes it clear that Nietzsche rejects - as 'hostile to life, a destroyer and dissolver of man' - commitment to 'a legal system' directed to making the conditions of justice 'sovereign and universal'. Surely profound admiration for an unconditionally just orientation simply cannot be squared with that rejection.

But, despite initial appearances, I think the passage does not counter my proposed reading in either of these ways. On the contrary: I think that close attention to what Nietzsche writes here 
helps both to clarify the reading I propose, and also to strengthen the case in favor of it. I shall engage in turn with each of the considerations mentioned in the previous paragraph.

To respond to the first of them, we need to go back to my earlier sketch of why Nietzsche can plausibly be regarded as expressing profound admiration for an unconditionally just orientation. I said that in the passage we were pondering, the adherence to justice Nietzsche envisages is one on which there are no conditions: this person described by Nietzsche will retain 'the just eye' under even the most extreme assault of 'injury, derision, accusation'. There is simply no suggestion there that this orientation must be grounded in a further fact, to the effect that justice is 'in itself' unconditionally valuable. For Nietzsche (I suggest) the unconditionality is realized that is, given substance or reality - in the mode or manner of valuing. In that case, the form of words 'justice is unconditionally valuable' will have a coherent use only as an echo, or recapitulation, of a readiness to affirm justice unconditionally in the way we've spoken of. As an attempt instead to ground such an affirmation in a supposedly prior reality of justice as unconditionally valuable, use of that form of words is wholly empty. To be clear: to hold that justice is in itself unconditionally valuable is on Nietzsche's outlook empty - an empty metaphysical gesture - unless that form of words is no more than a misleading way of registering a whole-hearted readiness to remain just come what may.

This view, I am suggesting, is already implicit in the passage with which we began. Nietzsche's insistence in the present passage that talk of justice 'in itself' - and so of the unconditional value of justice 'in itself' - is devoid of sense, is best read as an explicit expression of just that view. As such it is perfectly consistent with reading Nietzsche as whole-heartedly affirming the unconditionally just orientation of his 'piece of perfection'. The coherence of such an orientation, and so of his whole-hearted affirmation of it, simply does not, on Nietzsche's view in the Genealogy, depend at all on the intelligibility of 'talk of justice in itself'. ${ }^{14}$

So much (for the moment) for the first of the considerations from that passage that might have seemed to put paid to my reading. Before turning to the second consideration I mentioned, there 
is something else we need to get clear on here if we are not to misread Nietzsche: what is at issue in asking whether justice has intrinsic (by contrast with unconditional) value? Here I draw on Bernard Williams, who writes thus in connection with Plato's understanding of justice:

'something is intrinsically good if we need to value it as intrinsically good, and we can make sense of our doing so'. ${ }^{15}$ And so, Williams continues: 'The notion of something's being an intrinsic good will be explained in terms of a more basic notion of someone's valuing something as an intrinsic good'; adding that 'This means, of course, that we cannot explain "we value $\mathrm{X}$ as an intrinsic good" as "we value X because we believe that it is an intrinsic good"., 16 This account of intrinsic good gives primary place to the manner of valuing, much as my remarks on 'the unconditional value of justice' did. When justice is valued as an intrinsic good, then (roughly) the one who values it that way takes 'it is just' as itself a potentially compelling reason for doing it or for endorsing the doing of it. When justice is valued as an extrinsic good, by contrast, then it is valued for something else - for example, for helping keep the peace, or (rather differently) for the esteem from others that one's just observance earns. In Human, All Too Human Nietzsche seems to take it that justice operates only as an extrinsic good - specifically as something people value only for the esteem from others that they earn by adhering to justice. ${ }^{17}$ But his view in the Genealogy is different. There his broader account of justice - not just what he says about the 'piece of perfection' - allows for justice to be intrinsically valued, in a way not envisaged as possible in the earlier work. Through the process of moral acculturation by which 'the eye is trained for an ever more impersonal appraisal, even the eye of the injured one himself', one can become someone for whom holding oneself to a course 'simply because it is just' is a partial expression of who one is. And thereby one becomes someone able to value justice intrinsically. In this way, I suggest, Williams' account of Plato's understanding of what it is for justice to be an intrinsic good finds ready application to Nietzsche's picture of justice in the Genealogy.

In Human, All Too Human Nietzsche seems to think that while someone might give 'because it is just' as their reason for acting, we do not get to their real motivation until we see through that 
formulation to some further commitment it disguises - a commitment to seeking esteem from others, for example, or perhaps to helping keep the peace. While in the Genealogy he certainly does not exclude such motivation for acting justly - what he says there allows for its being commonly operative - Nietzsche now also acknowledges the human resources for a motivation to justice that is sufficiently expressed as: 'simply because it is just'. (And we have already rehearsed the story he tells about how people come to be so constituted that this could motivate them.) Nietzsche thus can readily allow that people can, and even characteristically do, simultaneously value justice both as an extrinsic good and as an intrinsic good. ${ }^{18}$ (As already noted, the training Nietzsche speaks of may in some rare cases not take effect at all, or, much more often, it may do so only partially. Those in whom it does not take effect at all will be wholly unsusceptible to considerations of justice. Those in whom the training takes partial effect will have a motivation to justice that reflects their valuing it as only an extrinsic good.)

So, by the time of the Genealogy Nietzsche has come to appreciate that a genealogical account of justice does not exclude people being motivated simply by the recognition that (for example) 'to do otherwise would be unjust' - expressed and understood in just those terms. But valuing justice thus intrinsically is not thereby valuing it unconditionally. One who regards justice as intrinsically valuable (that is, as non-derivatively valuable in the sense I've explained) need not be ready to affirm it come what may - in the face of whatever continuing injury or assault she may be subject to by refusing to act unjustly. Someone may be moved to act justly even at some fairly significant cost to her, and moved to do so 'simply because it is just', but still find herself drawing a line at some point well short of the orientation of the truly just person Nietzsche envisages. (Valuing justice intrinsically is thus necessary, but not sufficient, for valuing it unconditionally.) Indeed, as I read him this is how Nietzsche takes it to be for most people - even the 'most righteous' of people - most of the time. Most people will find their readiness to act justly 'because it is just' conditional on certain limits: that the 'injury', to them or to those they love, of responding justly not be too demanding or costly. In this way they will, in 
their valuing of justice, show themselves stopping short of the 'piece of perfection' who is Nietzsche's unconditionally just person.

I've shown how speaking of justice an sich as 'devoid of all sense', as Nietzsche does in 2.11 of the Genealogy, is perfectly compatible with recognizing that justice can be valued not only intrinsically but even unconditionally; and I've shown also why it is plausible to read Nietzsche as appreciating this. That still leaves the second difficulty posed by that long passage in 2.11 to my reading of Nietzsche on justice in the Genealogy. The second difficulty was this. Nietzsche clearly rejects commitment to 'a legal system' designed to impose 'conditions of justice' as 'sovereign and universal', because he sees this as commitment to 'a principle hostile to life, a destroyer and dissolver of man'. But to unconditionally value justice is surely to be committed to making conditions of justice thus prevail as 'sovereign and universal'. Since Nietzsche rejects that commitment, he cannot be read as whole-heartedly affirming an unconditional orientation to justice in his 'piece of perfection'.

But this line of argument does not hold. To be sure, unconditionally valuing justice does involve accepting any 'restrictions on the true will of life' that result from acting on the judgment of one's 'just eye'. But I think Nietzsche is plausibly read as ready to affirm the acceptance of such restrictions when they are the cost of someone's remaining just. Such acceptance, however, does not entail commitment to 'a legal system [of justice] conceived of as sovereign and universal'; nor does it entail endorsement of 'Dühring's communist cliché that every will must accept every other as equal'. Acceptance of such restrictions is perfectly compatible with holding that 'a legal system of justice as sovereign and universal' (along with 'Dühring's communist cliché) is 'a principle hostile to life, a destroyer and dissolver of man'; and again, I think Nietzsche appreciates this. But these claims may sound implausible. So let me set out in turn why I think each is true.

The first issue is whether Nietzsche really can plausibly be read as affirming a readiness to accept whatever 'restrictions on the true will of life' result from readiness to remain just, come 
what may. It needs stressing that such acceptance is wholly compatible with thinking those restrictions are a real loss, in some cases even a devastating and tragic loss. Suppose someone found she simply could not act unjustly - by, say, sacrificing the life of an innocent stranger even to save the life of the person dearest to her. In Nietzsche's terms: even under that devastating 'assault' she retains 'the just eye'. Such a response is perhaps a good candidate for exemplifying an unconditional adherence to justice. ${ }^{19}$ But someone who thinks and responds that way might also recognize - in deep anguish - that so responding will destroy something crucial to her living. The true story of Frau Paul in Anna Funder's book Stasiland exemplifies something very close to this pairing of responses. Arrested in February 1963 for harboring students trying to escape East Germany, Frau Paul was offered a deal by the Stasi. In West Berlin, an East German called Michael Hinze, whom Frau Paul knew, was helping people escape from the East. If Frau Paul would set up a meeting in West Berlin with Hinze - the obvious purpose of which was to enable the Stasi to capture him - they would let her visit her infant son, Thorsten, critically ill in a West German hospital to which he had been sent shortly before the Wall was built. Frau Paul refused to do it and was sentenced to four years hard labor. As Anna Funder records Frau Paul:

'Me - bait in a trap for Michael! And of course that was an absolute no. I couldn't.... But I did,' she draws in breath in a spasm of pain, 'decide against my son. ${ }^{20}$

While Frau Paul does not herself use the words 'justice' or 'injustice', it seems no distortion of her thinking to say that she could not do the Stasi's bidding because of the radical injustice she would thereby do Michael Hinze. At the same time she is agonizingly aware that her (unconditional) affirmation of justice here entails - to use Nietzsche's terms - a 'restriction' of the 'will of life' that courses through her love for her son. Even years later, while still fully recognizing the devastating cost of accepting that restriction of the 'will of life' in her, Frau Paul never rescinds her conviction that she did what she had to do. There is no suggestion in Funder's book that Frau Paul's acceptance of this restriction of 'the will of life' in her compromises the extraordinarily admirable character of what she did. On the contrary, this acceptance is an 
important source of Michael Hinze's own admiration, and also Funder's admiration, for what Frau Paul did. Michael Hinze said to Funder:

'I told her [Frau Paul] that her story moved me deeply'; and that 'I did not know many people who would not have betrayed me. I said that there are not many people who have the courage she did. To behave with' - he's looking for a way to describe it - 'with such great humanity, can I say. She behaved with such great humanity.' We are both silent for a moment. 'But unfortunately,' he says, 'at her cost.' ${ }^{22}$

Michael Hinze sees Frau Paul as responding vitally and with 'great humanity' to her situation.

(Nietzsche speaks of the one who remains just in such circumstances as seeing and responding 'deeply' and 'generously'.) If she does accept a restriction on her 'true will of life', that is only because it is a cost of her answering to something else that is also a 'true will of life' in her. He finds profound affirmation, including self-affirmation, in her response, even though it is also a tragically painful affirmation. I see no reason why Nietzsche could not share Hinze's view, and certainly nothing in the passage from 2.11 to suggest that he could not.

There would be reason for thinking Nietzsche could not share Hinze's view if Nietzsche were plausibly read as holding that any acceptance of such a restriction on 'the will of life' had to reflect 'a principle hostile to life'. But a careful reading of Nietzsche's passage will not find any such necessity being mooted. The principle there said to be 'hostile to life' is commitment to 'a legal system conceived of as sovereign and universal', or to 'Dühring's communist cliché that every will must accept every other will as equal'. My reading of Nietzsche on justice will be imperiled only if he is to be read as thinking that an unconditionally just orientation requires such commitment.

Here are two questions: 'Does an unconditionally just orientation require such commitment?'; and: 'Does Nietzsche think it does so?'. I think the answer to both questions is 'no'. A propos the first question, consider Frau Paul again. She did not say, and we do not have to suppose she thought: 'I couldn't betray Michael Hinze because I am committed to a legal system of justice as 
sovereign and universal'; or: 'I could not betray him because all wills are of equal value and his is one of the wills to which this principle applies'. What follows the 'because' in each of those sentences does not seem to form any part of her reason for finding it impossible to betray Michael. Her response makes perfectly clear sense independently of what follows those 'becauses'. What makes sense of her response is, simply, that she cannot betray Michael, this innocent person. (The force of calling Michael Hinze 'innocent' here is simply that his apprehension by the Stasi would have been unjust.) That does not imply that she would have been ready to betray some other innocent person - I think her response shows she would not. But if she would not, that is not because what is doing the real work in her response is her commitment to an abstract principle about the equality of all wills. If it had been someone other than Michael, then it would have been that innocent person she could not betray. Her response is not derived from any such principle. If her response does indeed carry within it a certain kind of universality, it is not a kind describable in the terms Nietzsche objects to. If it were so describable, then for Frau Paul the really terrible thing about betraying Michael would have to be that it involved her abandoning a commitment to the equality of all wills, or to a legal system of justice as sovereign and universal. But as already noted it is perfectly clear from what Frau Paul says that the really terrible thing would have been the betrayal of this man, Michael Hinze; and if it had been someone else the terrible thing would have been her betrayal of that specific person. If there is a kind of universality implicit in her response, it is a universality given its sense and held in place by an ineliminably indexical, experiential dimension of vital response to this specific other.

Similarly, Nietzsche's affirmation of the just orientation described in our starting passage implies no commitment to those attitudes he finds 'hostile to life, a destroyer and dissolver of man, an attempt to kill the future of man'. We would be completely distorting Nietzsche's example if we imagined his 'just man' remaining just 'because he is committed to a legal system of justice as sovereign and universal', or 'because he thinks all wills are of equal value and the will of the one who has wronged him his is one of the wills to which this principle applies'. (And 
Nietzsche says nothing at all to encourage the idea that he thinks his 'piece of perfection' is saddled with such commitment.) But if this is right, then the unconditionally just orientation that I say Nietzsche deeply admires has nothing to do with a commitment to making the conditions of justice 'sovereign and universal' and to 'Dühring's communist cliché'. The attitudes hostile to life that Nietzsche there excoriates in such a commitment simply do not belong to expressions of that unconditionally just orientation he profoundly affirms. It will help to strengthen this claim if I can say a bit more to clarify just what then is the object of Nietzsche's hostility in the passage we are considering.

In that passage, Nietzsche contrasts recognizing the conditions of justice as 'exceptional conditions' with the invidious attempt to make the conditions of justice 'sovereign and universal' Let us label that attempt an attempt to 'maximize' the conditions of justice. A key point is then that the unconditionally just orientation Nietzsche so admires does not involve a commitment to maximizing the conditions of justice. One issue here concerns the 'universalizability' of moral judgment. It is commonly held that if I reckon myself morally required to do (or not to do) $\mathrm{X}$ in a certain situation I must (logically) reckon all others in a relevantly similar situation to be so required. It is well-known that Nietzsche rejected this view; and his objection to it was essentially moral: that there was something impertinent or presumptuous - perhaps even 'hostile to life'? in presuming to commit 'everyone' to one's own values. I read his 'just man' in the light of that rejection: Nietzsche's description of him carries no suggestion that this person must 'will' that all others also remain just 'come what may'; he is presented simply as this person who wholeheartedly responds thus. (Nor does Nietzsche suggest that others 'must' admire this 'piece of perfection'. He just makes it clear that he does so - and the reader may well then find herself wondering if she might share his attitude.) It is likely that Nietzsche's objection to 'maximizing' the conditions of justice then includes his objection to 'universalizability' as a supposed condition of ethical judgment. But that is not my main concern here. A contrast drawn by Philip Pettit between 'honoring' and 'promoting' a value may help to clarify what I do want to focus on. ${ }^{23}$ 
Suppose someone recognizes that by herself acting unjustly in a particular situation she could very likely increase the 'conditions of justice' more than she would by herself remaining just in that situation. There are familiar examples from the literature on consequentialism: one of them is the sheriff scape-goating the innocent person the mob is after, to minimize the mob's rampant injustice. The idea is that by doing something unjust - scape-goating this innocent person - one may be overall reducing the incidence of injustice (by minimizing the unjust rampages of the mob) and so increasing 'the conditions of justice'. In Pettit's terms the suggestion then is that, in deciding for this reason to do this specific unjust thing, a person might well be showing her commitment to promoting justice, even while not herself here honoring it in her own action. Conversely, if she refused to act unjustly herself in the circumstance described this would show her commitment to honoring justice rather than to promoting it. If honoring a value and promoting it are thus distinguishable orientations, then one person might unconditionally honor justice while another was unconditionally committed to promoting it. In the terms of this contrast, a commitment to maximizing the conditions of justice - for example through one's willing participation in and commitment to 'a legal system [of justice] conceived of as sovereign and universal' - belongs to a commitment to promoting justice. This is very different from the orientation of Nietzsche's 'piece of perfection', exemplified in his retaining the 'just eye' come what may. That is better seen as, instead, an unconditional honoring of justice.

Of course, someone thus oriented might also seek to promote justice. (She could not do that unconditionally, though; for if she unconditionally honored justice she would have to cease 'promoting' it when doing that would require her to act unjustly.) But Nietzsche's admiration is not for promotion of justice. Indeed, so far as promotion of justice involves 'commitment to a legal system [of justice] as sovereign and universal' Nietzsche is strongly opposed to it. Perhaps, though, there are ways of promoting justice that don't involve such commitment: the just man Nietzsche envisages, for example, may in fact 'promote' justice just by the effective influence his example exercises - other people witness him and may be moved to emulate him; or he might 
perhaps admonish his children when they behave unjustly; or he might influence those around him by the admiration he expresses for other just people. It is worth noting that even if Nietzsche's admiration is not for the promoting of justice, he need not despise its promotion when that takes these latter forms. His contempt is specifically targeted at the promoting of justice as expressed in 'commitment to a legal system of justice as sovereign and universal', and in commitment to Dühring's 'communist cliché'.

One might of course take issue with someone's favoring honoring justice over promoting it. Pettit himself does so: as a consequentialist he thinks promoting value is the more important of the two. But that is another matter. The relevant point here is simply that if we make sense of Nietzsche's view in terms akin to Pettit's contrast, there is no inconsistency in seeing him as profoundly affirming what I am here calling the honoring of justice (as manifested in the orientation of his 'piece of perfection') and at the same time as hostile to (something very like) its unconditional promotion. Nietzsche's vigorous resistance to 'a legal system [of justice] conceived of as sovereign and universal' and to Dühring's dictum 'that every will must accept every other will as equal' is then perfectly compatible with his deep affirmation of remaining always just in one's own responses, come what may. (Incidentally, the kind of commitment to justice Nietzsche rejects is linked to his remarks on the 'administration' of justice. These remarks are initially historical - they concern a cultural/political transformation originally effected by aggressive 'stronger powers'. At the end of 2.11 Nietzsche turns to what he thinks is a destructive transformation of 'the law' originally established by those stronger powers, into 'a legal system conceived of as sovereign and universal'.)

I conclude that nothing in that long passage from the end of 2.11 undermines reading the Nietzsche of the Genealogy as profoundly affirming an unconditionally just orientation in his 'piece of perfection'. On the contrary, reflection on that passage has helped both to clarify and strengthen the case for reading Nietzsche in just this way. 
Nietzsche's hostility to justice in the form of 'a legal system conceived of as sovereign and universal' is implicitly hostility to justice conceived of as any system of rules, or as any system at all. That is of a piece with his broader hostility to any and all 'systems' of ethics. (The very noun 'ethics' perhaps already takes the life out of Nietzsche's concern with value.) In this connection it is worth re-iterating something else I've already spoken about. I have read Nietzsche as expressing profound regard for what I have called an unconditionally just orientation. The 'unconditionality' here is recognized to lie in the manner or mode of valuing, in the lived attitude or orientation of a human being, and not in the fixed being of an external 'object' nameable as 'justice'. With this in mind, there is point in seeing Nietzsche as fashioning a conception of 'virtue ethics' - a long time ahead of an Anglophone turn to that theme. Of course we can also see him doing that in other places as well as the Genealogy. But it is only in the Genealogy, so I have argued, that Nietzsche comes to appreciate that his hostility to 'metaphysical' ethics does not entail hostility to an orientation that can full-bloodedly be thought of as 'unconditional' - of course when we understand that in the right way. Even in Human, All Too Human Nietzsche still spoke as if regarding talk of justice an sich as 'devoid of all sense' entails thinking the same about an unconditionally just orientation. In the Genealogy, this is no longer so.

I do not say that Nietzsche himself was clear-sighted with respect to every element of the reading of him that I have given. In itself that is of course a rather mild claim: every reading of a text in some way goes beyond the author's say-so - minimally so by the very act of doing other than simply repeating his or her actual words. More strongly though: I've drawn on philosophical themes developed by others in elaborating and justifying my reading. I've suggested that coming to Nietzsche's text in the light of those themes helps to yield a fruitful reading of it, if not a reading that is free of all internal tension. (Nietzsche's work is itself part of the source of the theme from Bernard Williams that I've drawn on.) One might speak here of Nietzsche's philosophical honesty. Perhaps this is a quality shared, in varying forms, by all great philosophers. But it is especially prominent in Nietzsche: often he registers a specific local point, insight, idea, 
as truthfully and vividly as he can, without immediate regard for how, or even whether, it may be reconcilable with the broader context in which he registers it. This practice dovetails with his insistence that his reader work hard: each reader is tasked with making something of the whole, by due attention to its parts, but also with remaining ready to wrestle with the difficulty of finding aspects of various parts to be in tension with any plausible reading of the whole. That wrestling may then be the spur to a further creative philosophical move by the reader. It is integral to Nietzsche's understanding of philosophy, and to his own practice of it, that philosophizing is in this way an agon, a continuing struggle. He enacts his own agon, and in doing so implicates the reader in taking that agon up in her own distinctive way.

The passage from the Genealogy with which we began - about the 'piece of perfection' - fits this picture. In it Nietzsche sets out something he finds compelling - something not derived from any general theory or position - and implicitly invites his reader to make sense of it, if she can, in the broader context of what he writes. (If she cannot, nothing is thereby proven; but a further task or challenge then faces her.) I have tried to provide a wider reading that gives its due to that extraordinary passage. In undertaking to do that, I have cast various other passages from Nietzsche's text in a rather different light from usual. Sometimes this may even be a light in which Nietzsche himself does not clearly see what he has written. But that, too, is not something Nietzsche should be supposed hostile to. If anyone is open to recognizing that various aspects of what a philosopher writes will be to some extent obscure to her, perhaps sometimes even at odds with what she sincerely and explicitly professes, it is Nietzsche!

That observation is of course not a blank check to fund any old reading of some aspect of Nietzsche's thought. Any tensions between my reading and other Nietzsche themes and passages must be taken seriously. Two important questions for the reader of this essay are whether the reading proposed is fertile and productive, and whether, even if it is so, there may remain tensions with other aspects of Nietzsche's work so strong as still to kill the reading.

\section{University of Melbourne}


$\underline{\text { Notes }}$

1. F. Nietzsche, On the Genealogy of Morality, trans. Maudemarie Clark and Alan Swensen (Indianapolis/Cambridge: Hackett Publishing Company, 1998), Essay 2:11 [48-49]. All quotations from the Genealogy are from this translation, and referenced by Essay and Section number.

3. I shall come back to reflect further on the idea of unconditional affirmation, and on whether it is incompatible with other deep themes of Nietzsche's.

4. Genealogy, 2:11.

5. Ibid.

6. Ibid.

7. Genealogy, 2:8. A similar thought finds expression in Human, All Too Human; Beyond Good and Evil; The Wanderer; and Daybreak. Nietzsche refers to the latter two texts in the Preface to the Genealogy.

8. Ibid.

9. 'Sketched' is the right word: Nietzsche's story about the emergence of justice is indeed a sketchy one, lacking in detail. He seems to think that what matters is to shift the direction of our thinking by making it plausible that justice as we now have it could indeed have 'come to be' by some such historical process, rather than to establish the precise details of

the actual process.

10. Foucault's theme of history as a succession of ruptures draws directly on these ideas of Nietzsche's: '[Genealogized history] will uproot [history's] traditional foundations and relentlessly disrupt its pretended continuities'. Michel Foucault, "Nietzsche, Genealogy, History", in The Foucault Reader, ed. Paul Rabinow (New York: Pantheon Books, 1984), 88.

11. Genealogy, 2:12. In framing his point here as one about 'all happening in the organic world', Nietzsche is drawing his bow more widely than is needed to cover the human phenomena I am concerned with in this essay.

12. There is, to my ear, a subtle difference in the tone of this passage from the ostensibly similar familiar passage in Beyond Good and Evil, in which Nietzsche scorns as 'fools' the 'metaphysicians' who think that 'things of the highest value must have a different origin, an origin of their own-in this transitory, seductive, illusory, paltry world, in this turmoil of delusion and cupidity, they cannot have their source.' (Beyond Good and Evil, Ch. 1 "Prejudices of Philosophers", Para. 2.) In the Genealogy Nietzsche still scorns those he calls the 'metaphysicians', but his conception there of the genealogical alternative to metaphysics is richer, more flexible and less reductive than in the passage from Beyond Good and Evil.

13. I take this point further below, via a related contrast between honoring and promoting justice.

14. Genealogy, 2:11.

15. Prior to the Genealogy things are different. Even in Human, All Too Human Nietzsche speaks as if rejection of talk of justice an sich excludes the possibility of unconditional and intrinsic valuing of justice. I undertake to sort out some of (what I hold to be) the shift in his thinking on this below.

16. B. Williams, "Plato's Construction of Intrinsic Goodness", in B. Williams, The Sense of the Past (Princeton University Press, 2006), 136. Williams draws on the Republic as well as on the Gorgias in developing his account of this Platonic 'construction'. It may sound 
strange to suggest that an account of justice in Plato can illuminate Nietzsche on justice. In fact I think there are closer links between Plato and Nietzsche here than my limited use of Williams' essay suggests. But that is another matter!

17. Ibid.

18. Nietzsche, Human, All Too Human, trans. M. Faber (University of Nebraska Press, 1984), Aphorism 92.

19. Plato says the same in the Republic. Williams (op. cit., 137) endorses Plato's claim there that justice is good (in Williams' terms) both intrinsically and extrinsically. And, though speaking of trust and trustworthiness rather than justice, he adds this about the relation between those modes of valuing: "we have to regard these things [trust and

trustworthiness] as intrinsically good if they are even to be derivatively good, since many

of their good effects, and indeed their existence, depend on their being valued as intrinsic goods"

20. Skepticism about the likelihood of someone responding this way is not to the point. As noted earlier, Nietzsche insists on caution about the likelihood but recognizes the possibility, and thinks its realization would be deeply admirable.

21. A. Funder, Stasiland (Melbourne: Text Publishing, 2002), 220-21.

22. Op. cit., 229.

23. The contrast is developed in Philip Pettit, "Consequentialism and Respect", Ethics 100, October 1989, 116-126.

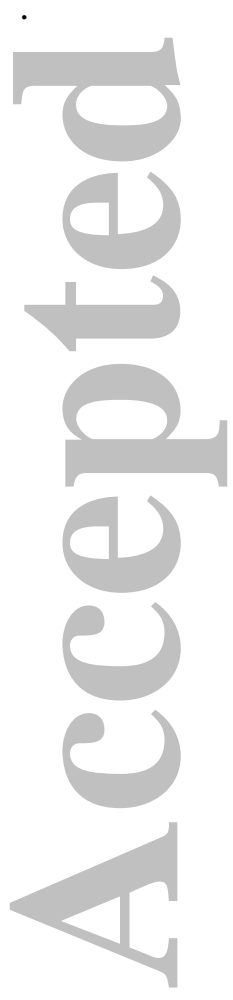




\section{University Library}

\section{- M M I N E R VA A gateway to Melbourne's research publications}

Minerva Access is the Institutional Repository of The University of Melbourne

Author/s:

Cordner, CD

Title:

Justice and Unconditional Valuing in Nietzsche's genealogy

Date:

2017-01-01

Citation:

Cordner, C. D. (2017). Justice and Unconditional Valuing in Nietzsche's genealogy. PHILOSOPHICAL FORUM, 48 (1), pp.49-67. https://doi.org/10.1111/phil.12145.

Persistent Link:

http://hdl.handle.net/11343/292284 